\title{
Geochemistry and mineralogy of critical metals (PGE, Co, REE, Sc) in supergene deposits
}

\author{
CRISTINA VILLANOVA-DE-BENAVENT ${ }^{1}$, THOMAS
}

AIGLSPERGER $^{2}$ AND JOAQUÍN A. PROENZA ${ }^{1}$

${ }^{1}$ Universitat de Barcelona

${ }^{2}$ Luleå University of Technology

Presenting Author: cvillanovadb@ub.edu

Recently, critical metals (CM) have become a hot topic, because of the increase in demand for their use in green energy technologies, and the high risk of supply. Platinum Group Elements (PGE), Co, Rare Earth Elements (REE), and Sc are among them, and found in economic concentrations in unconventional deposits like laterites and bauxites.

Firstly, laterite deposits have been targeted especially for PGE, $\mathrm{Co}, \mathrm{Sc}$, and may contain remarkable REE. On one hand, laterites formed after weathering of ophiolite-derived ultramafic rocks (so-called "Ni-Co laterites"), can be enriched in PGE and Co. Total PGE contents slightly increase from the parent rock to the lower, saprolite horizon, and are highest in the upper, limonite horizon. At least three types of PGE minerals (PGM) can be found: i) primary inclusions in chromite; ii) secondary (modified by serpentinisation or weathering) PGM; and iii) neoformed (precipitated) after PGE mobilisation within the laterite. The lithiophorite-asbolane series are the main source of Co, concentrated in the transition zone of the weathering profiles.

On the other hand, oxide-rich laterites derived from UralAlaskan-type complexes have low $\mathrm{Ni}$ concentrations, but are world class Sc deposits, yielding higher grades than Ni-Co laterites. In these environments, $\mathrm{Sc}$ is mostly hosted in goethite, but also in Mn oxyhydroxides.

Secondly, karst bauxite deposits are important unconventional sources of REE (La-Lu, Y), with the additional advantage of containing low Th and U. REE-bearing minerals in this environment include primary phosphates (e.g., monazite); and secondary phosphates (rhabdophane, churchite, florencite), carbonates (bastnäsite, tengerite) and oxides. Each of them may have a different REE signature, and ore processing of secondary REE-minerals is usually easier.

While certain CM are already extracted from some supergene deposits, these environments may become important targets for others, in the upcoming transition towards a future of zero emissions. However, the key point is to identify the mineral that hosts the CM in these deposits. 